\title{
Assessment of sediment metal contamination in the Mar Menor coastal lagoon (SE Spain): Metal distribution, toxicity, bioaccumulation and benthic community structure
}

\author{
Valoración de la contaminación por metales en los sedimentos \\ de la laguna costera del Mar Menor (SE de España): \\ Distribución de metales, toxicidad, bioacumulación y estructura de las comunidades bentónicas
}

\author{
Lázaro Marín-Guirao ${ }^{1 *}$ \\ Augusto Cesar ${ }^{2}$ \\ Arnaldo Marín ${ }^{1}$ \\ Rubén Vita ${ }^{1}$ \\ ${ }^{1}$ Departamento de Ecología e Hidrología \\ Facultad de Biología \\ Universidad de Murcia \\ 30100-Murcia, Spain \\ *E-mail: lamarin@um.es \\ ${ }^{2}$ Departamento de Ecotoxicología \\ Universidade Santa Cecilia \\ Santos, 11045-907, SP, Brazil
}

Recibido en marzo de 2004; aceptado en enero de 2005

\begin{abstract}
The Mar Menor coastal lagoon is one of the largest of the Mediterranean Sea. Ancient mining activities in the mountains near its southern basin have resulted in metal contamination in the sediment. The metal bioavailability of these sediments was determined through laboratory toxicity bioassays using three Mediterranean sea urchin species and two amphipod species, and by means of field bioaccumulation measurements involving the seagrass Cymodocea nodosa. The effect of sediment metal contamination on benthic communities was assessed through benthic infaunal analyses, applying classical descriptive parameters and multivariate techniques. The sediments affected by the mining activities presented high levels of toxicity and metals were also accumulated in the seagrass tissues, pointing to metal bioavailability. Although the classical benthic indices were not clear indicators of disturbance, the multivariate techniques applied provided more consistent conclusions.
\end{abstract}

Key words: metals, toxicity, bioaccumulation, amphipods, sea urchins, seagrass, coastal lagoon, Mediterranean Sea.

\section{Resumen}

El Mar Menor es una de las mayores lagunas costeras en el Mediterráneo. Actividades mineras desarrolladas históricamente en las montañas situadas en su orilla sur han causado la contaminación por metales de sus sedimentos. La biodisponibilidad de los metales en estos sedimentos fue determinada por medio de bioensayos de toxicidad, empleando tres especies de erizos marinos y dos especies de anfípodos, y por medio de medidas de bioacumulación en la fanerógama marina Cymodocea nodosa. El efecto de la contaminación de los sedimentos por metales en las comunidades bentónicas fue valorado a través de análisis de la infauna bentónica, aplicando parámetros descriptivos clásicos y técnicas multivariantes. Los sedimentos afectados por las actividades mineras presentaron altos niveles de toxicidad y estos metales fueron incluso acumulados en los tejidos de la fanerógama marina, indicando la biodisponibilidad de los mismos. Aunque los índices bentónicos clásicos no resultaron ser claros indicadores de la perturbación, las técnicas multivariantes aplicadas ofrecieron conclusiones más consistentes.

Palabras clave: metales, toxicidad, bioacumulación, anfípodos, erizos marinos, fanerógama marina, laguna costera, Mar Mediterráneo.

\section{Introduction}

Coastal lagoons and estuaries are physicochemically unique because of their strong gradients in salinity, temperature, $\mathrm{pH}$, dissolved oxygen, redox potential, sediment

\section{Introducción}

Las lagunas costeras y los estuarios son sistemas con características fisicoquímicas únicas debido a los fuertes gradientes de salinidad, temperatura, $\mathrm{pH}$, oxígeno disuelto, potencial 
chemistry and species composition. Moreover, they can fundamentally be considered as receivers of sediments that act as a trap for materials. Sediments serve as a filter for many contaminants between land and sea, and not only accumulate metals but also act as a source of contaminants to marine biota (Ingersoll, 1995). However, specific toxicity and other environmental assessment methods for the sediments of lagoons or estuaries are few and relatively new, since many marine and fresh-water techniques are not generally applicable. Lagoons tend to have a low number of species and low species diversity compared with fresh or marine waters, and for this reason traditional univariate analyses of populations can be difficult to interpret in such naturally stressed environments. Hence, ecological stress, from any source, is best measured using multivariate methods and analyses (Chapman and Wang, 2001).

The study area is located in Mar Menor, SE Spain, one of the biggest coastal lagoons in Europe and the Mediterranean Sea. The lagoon is relatively shallow, with a mean depth of $3.5 \mathrm{~m}$ and a maximum depth of just over $6 \mathrm{~m}$. La Manga, a sandy bar (22 km long) crossed by five channels that regulate the water circulation with the Mediterranean Sea, encloses the lagoon. Owing to the low fresh-water input and the high level of water evaporation, the salinity values of the lagoon range between 42 and 47. Common shallow-water species of the Mediterranean Sea inhabit the lagoon. The semi-arid climate of SE Spain means that watercourses remain dry for a 5-10 year period, and fresh water does not reach the lagoon unless sporadic and torrential rainfall occurs. For several centuries two watercourses, the Beal and Ponce wadis, have brought to the lagoon drainage and sedimentation wastes associated with mining activities and abandoned mined lands. In fact, the mining activity in the mountains enclosing the southern part of the lagoon was amongst the most substantial in Spain in the last two centuries. All mining activities ceased in 1991, but during flood episodes the metals of mine tailings are released into the Mar Menor lagoon. Mine tailings may release and leach metals for several hundreds of years after the mining activity has ceased (Gundersen et al., 2001). Previous studies carried out in the area showed $\mathrm{Zn}, \mathrm{Pb}$ and $\mathrm{Cd}$ to be the main metals remaining from the mining activity and released into the environment (Simoneau, 1973; De Leon et al., 1982).

In the present study we have tested sediment toxicity using three species of sea urchin, Arbacia lixula (Linné), Paracentrotus lividus (Lamarck) and Sphaerechinus granularis (Lamarck), and two species of amphipod, the burrowing amphipod Microdeutopus gryllotalpa (A. Costa) and Siphonoecetes sabatieri (Rouvile), employed for the first time in toxicity testing. The bioavailability of metals was also determined by studying the bioaccumulation of metals in different fractions (leaves, rhizomes, roots) and in leaf-biofilm of the seagrass Cymodocea nodosa (Ucria) Aschers. To determine the effect of mineral wastes on the benthic communities of Mar Menor, classical descriptive parameters were used together with multivariate analyses that distinguish anthropogenic stresses from natural events. redox, características químicas de los sedimentos y composición de especies. Por otra parte, estos sistemas pueden fundamentalmente ser considerados como receptores de sedimentos que actúan como una trampa para los materiales que llegan al medio marino. Los sedimentos sirven como filtro entre la tierra y el mar para muchos contaminantes, y no sólo acumulan metales sino que también actúan como una fuente de contaminantes para la biota marina (Ingersoll, 1995). Sin embargo, los métodos de valoración ambiental específicos para sedimentos de lagunas o estuarios, como los bioensayos de toxicidad, son escasos y relativamente nuevos, ya que las técnicas marinas y para agua dulce no son generalmente aplicables en estos sistemas. Las lagunas costeras suelen tener un bajo número de especies y una baja diversidad comparadas con aguas continentales o marinas, y por esta razón los análisis tradicionales de las poblaciones pueden ser difíciles de interpretar en estos ambientes naturalmente estresados. En este sentido, el estrés ecológico puede ser determinado de forma más confiable empleando métodos y técnicas multivariantes (Chapman y Wang, 2001).

El área de estudio está localizada en el Mar Menor (SE de España), una de las lagunas costeras más grandes de Europa y del Mar Mediterráneo. Esta laguna hipersalina es relativamente somera con una profundidad media de $3.5 \mathrm{~m}$ y una profundidad máxima de $6 \mathrm{~m}$. La laguna está delimitada por La Manga, una barra arenosa de $22 \mathrm{~km}$ de largo que se encuentra atravesada por cinco canales o golas que regulan el intercambio de agua con el Mediterráneo. La laguna tiene una salinidad entre 42 y 47 debido a que la tasa de evaporación supera al aporte de agua dulce por las ramblas. A pesar de su alta salinidad la laguna contiene especies típicamente marinas adaptadas a este rango de salinidad. El clima semiárido del sudeste ibérico propicia que las ramblas permanezcan secas durante periodos de años, alcanzando las aguas dulces la laguna sólo cuando ocurren lluvias torrenciales. Durante siglos las ramblas del Beal y Ponce han transportado a la laguna estériles mineros procedentes de las antiguas minas de la Sierra de Cartagena. Estas actividades mineras desarrolladas en las montañas situadas al sur de la laguna costera fueron de las más sustanciales en España en los últimos siglos y, aunque toda la actividad minera cesó en 1991, en la actualidad las ramblas siguen transportando estériles de minería ricos en metales durante los episodios de lluvias torrenciales. Los metales contenidos en los estériles mineros podrían liberarse y lixiviarse durante varios cientos de años tras el cese de la actividad minera (Gundersen et al., 2001). Estudios previos realizados en la zona mostraron que $\mathrm{Zn}, \mathrm{Pb}$ y Cd son los principales metales que permanecen de la actividad minera y que son liberados al medio ambiente (Simoneau, 1973; De Leon et al., 1982).

En el presente estudio hemos analizado la toxicidad de los sedimentos con tres especies de erizos marinos, Arbacia lixula (Linné), Paracentrotus lividus (Lamarck) y Sphaerechinus granularis (Lamarck), y con dos especies de anfípodos, Microdeutopus gryllotalpa (A. Costa) y Siphonoecetes sabatieri (Rouvile), empleado por primera vez en bioensayos 
The aim of the present study was to evaluate the environmental quality of the soft-bottoms from the southern basin of the Mar Menor lagoon influenced by historical mining activities. The concentration of metals in sediments and metal bioavailability were assessed through different approaches: (i) toxicity testing employing amphipods and sea urchin, (ii) accumulation measurements in the seagrass Cymodocea nodosa, (iii) physicochemical analyses measuring acid volatile sulfides and simultaneously extracted metals, and (iv) the study of benthic communities.

\section{Materials and methods}

\section{Sampling stations and study area}

Sampling stations were selected in the southern basin of the lagoon, with similar salinity and confinement ranges to minimize possible differences in structure and composition between populations due to the natural gradient characteristics of coastal lagoons. The location of the sampling sites and stations is shown in figure 1. Station UR (Los Urrutias) receives diffuse stormwater inputs and is influenced by the temporary Miranda stream located several hundreds of meters to the north. Station BW (Beal wadi) is located at the outlet of the temporary Beal stream historically employed to discharge mining wastes, and because of the existence of mine tailings in its head-area, great quantities of metals are introduced into the lagoon when torrential rains occur. Station PW (Ponce wadi), situated in the mouth of the temporary Ponce stream, shorter than Beal, channels the rainwater from mined areas where old mining wastes exist. Station PH (Playa Honda) is located near an urban area and a salt mine, midway between both wadis and

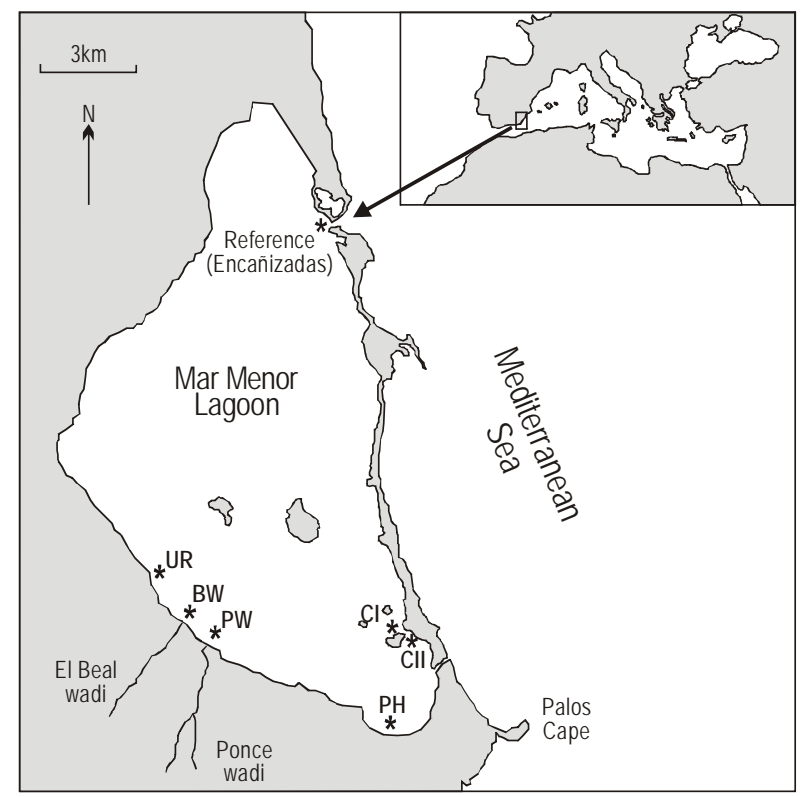

Figure 1. Map of the study area and location of the sampling stations. Figura 1. Mapa del área de estudio y localización de los puntos de muestreo. de toxicidad. La biodisponibilidad de los metales se determinó también estudiando la bioacumulación de metales en diferentes fracciones (hojas, tallos y raíces) y en el biofilm de las hojas de la fanerógama marina Cymodocea nodosa (Ucria) Aschers. Con el fin de determinar los efectos de los residuos mineros en las comunidades bentónicas del Mar Menor, se emplearon descriptores clásicos junto con análisis multivariantes para distinguir el estrés antrópico de los eventos naturales.

El propósito del presente estudio fue evaluar la calidad ambiental de los fondos blandos de la cuenca sur de la laguna del Mar Menor influenciada por actividades mineras históricas. La concentración de metales en sedimentos y su biodisponibilidad fueron valoradas por medio de varias aproximaciones: (i) pruebas de toxicidad empleando anfípodos y erizos marinos, (ii) medidas de acumulación en la fanerógama marina Cymodocea nodosa, (iii) análisis fisicoquímicos midiendo los sulfuros ácidos volátiles y los metales extraidos simultáneamente, y (iv) estudio de las comunidades bentónicas.

\section{Material y métodos}

\section{Estaciones de muestreo y área de estudio}

Las estaciones de muestreo fueron seleccionadas en la cuenca sur de la laguna con salinidad y grado de confinamiento similares, con el propósito de minimizar cualquier posible diferencia en la estructura y composición entre poblaciones debido a gradientes naturales característicos de las lagunas costeras. La localización de los puntos de muestreo y las estaciones se muestran en la figura 1. La estación UR (Los Urrutias) recibe entradas difusas durante los episodios de lluvias y se encuentra influenciada por la rambla de Miranda, localizada varios cientos de metros al norte. La estación BW se encuentra localizada en la desembocadura de la rambla del Beal, históricamente utilizada para descargar los desechos mineros y debido a la existencia de residuos mineros en su cabecera, gran cantidad de metales son introducidos en la laguna durante las lluvias torrenciales.

La estación de la rambla de Ponce (PW), situada en la desembocadura de la rambla de la que recibe el nombre y más corta que la del Beal, canaliza el agua de lluvia de antiguas zonas mineras donde existen restos de la minería. La estación PH (Playa Honda) está situada cerca de un área urbanizada y de unas salinas, a media distancia entre las estaciones de las ramblas y la estación CI, seleccionada como referencia en la cara norte de la Isla del Ciervo y localizada en la cuenca sur de la laguna costera, lejos de la influencia de las ramblas. Una segunda estación en el lado sur de la Isla del Ciervo (CII) fue seleccionada como segunda estación de referencia para los estudios de bioacumulación y de fauna. Para las pruebas de toxicidad con anfípodos seleccionamos una estación de referencia adicional en el canal de las Encañizadas, donde el anfípodo $M$. gryllotalpa era abundante. El canal de las Encañizadas, que permite la comunicación de las aguas de la laguna con el Mediterráneo, presenta características muy 
station CI, selected as reference in the north side of El Ciervo Island, situated in the southern basin of the coastal lagoon and far from the influence of both temporary streams. A second station on the south side of El Ciervo Island (CII) was selected as a second reference station for bioaccumulation and infaunal measurements. For toxicity assays with amphipods we selected an additional reference station in the Encañizadas channel where the amphipod $M$. gryllotalpa was abundant. The Encañizadas channel, which permits the communication of the lagoon waters with the Mediterranean Sea, presents very different characteristics compared with the other sites selected in the southern basin, so its faunal distribution was not studied.

\section{Collection of sediment, plants and organisms}

Sediment samples were collected with a hand-grab, taking the top $5 \mathrm{~cm}$ of the surface, and stored in 0.5-L polyethylene jars. Prior to sample collection and between uses, all the containers used for the collection and storage of sediments were thoroughly cleaned with acid $\left(10 \% \mathrm{HNO}_{3}\right)$. All samples were transported refrigerated to the laboratory to be stored in the dark at $4^{\circ} \mathrm{C}$, and subsampled for chemical quantification and toxicological characterization. Before testing, the sediment samples were homogenized and sieved, discharging large pieces of debris and potential predators. For the benthic infaunal samples $(n=4)$, an area of $0.09 \mathrm{~m}^{2}$ was sampled, collecting the superficial $5 \mathrm{~cm}$ of the sediment with a hand-grab. Organisms were removed by wet-sieving at the study site with a $0.5-\mathrm{mm}$ mesh, and preserved with $10 \%$ buffered formalin. Adults of the sea urchin species (A. lixula, P. lividus and $S$. granularis) were obtained by scuba diving in an unpolluted area of the Mediterranean Sea far from the lagoon (El Fraile Island, Aguilas). In the laboratory, the sea urchins were kept in glass aquaria with flowing natural seawater until used, and supplied with macroalga from their collection site as food. The amphipods (M. gryllotalpa and S. sabatieri) were collected from Las Encañizadas and El Ciervo island, respectively, two areas located within the coastal lagoon and selected as reference for the amphipod toxicity testing. Organisms were transported in polyethylene buckets containing collection site sediment and water, at a constant temperature. Before testing, experimental organisms were acclimated to test conditions.

\section{Toxicity}

Short-term chronic toxicity tests were performed with gametes of the sea urchins, according to the US Environmental Protection Agency (1995). The sea urchin A. lixula was stimulated to release gametes by touching the shell with steel electrodes connected to a 35- $\mathrm{V}$ transformer (about $10 \mathrm{~s}$ each time), whereas $P$. lividus and $S$. granularis were spawned by injection of $5 \mathrm{~mL} 0.5 \mathrm{M} \mathrm{KCl}$ through the peristomal membrane into the coelomic cavity. Four replicates were used per treatment and approximately 400 fertilized eggs were added to each test chamber. Experiments were conducted in a diferentes comparadas con las del resto de los puntos seleccionados en la cuenca sur, por lo tanto, no se estudió la distribución de su fauna.

\section{Recogida de sedimentos, plantas y organismos}

La muestras de sedimento fueron recogidas con una draga de mano, tomando los $5 \mathrm{~cm}$ superficiales y almacenándolos en botes de polietileno de $0.5 \mathrm{~L}$. Antes de la recogida de muestras y entre usos, todos los recipientes fueron lavados con ácido $\left(\mathrm{HNO}_{3}\right.$ al $\left.10 \%\right)$. Las muestras fueron refrigeradas durante su transporte al laboratorio, donde fueron almacenadas en la oscuridad a $4^{\circ} \mathrm{C}$ y subdivididas para los análisis químicos y la caracterización toxicológica. Antes de las pruebas de toxicidad, las muestras de sedimento fueron homogeneizadas y tamizadas, descartando grandes restos vegetales o depredadores potenciales. Las muestras para estudiar la estructura de la fauna bentónica fueron recolectadas con una draga de mano de $0.09 \mathrm{~m}^{2}$, tomando los primeros $5 \mathrm{~cm}$ del sedimento $(n=4)$. Para facilitar la separación de los invertebrados, las muestra fueron tamizadas con una malla $0.5 \mathrm{~mm}$ de luz y fijadas con formaldehído tamponado al $10 \%$. Los erizos adultos de las especies A. lixula, P. lividus y S. granularis fueron recogidos buceando en un área no contaminada del Mediterráneo lejos de la laguna (Isla del Fraile, Águilas). En el laboratorio los erizos fueron mantenidos en acuarios y alimentados con algas hasta su utilización. Los anfípodos M. gryllotalpa y S. sabatieri fueron recolectados en Las Encañizadas y la Isla del Ciervo, respectivamente, dos áreas localizadas dentro de la laguna y seleccionadas como referencias para los bioensayos con anfípodos.

Los organismos fueron transportados en contenedores de polietileno junto con sedimento y agua del lugar de recolección. Antes de las pruebas de toxicidad los organismos fueron aclimatados a las condiciones de las mismas.

\section{Toxicidad}

Se realizaron bioensayos de toxicidad con larvas de erizos siguiendo las recomendaciones de US Environmental Protection Agency (1995). El erizo A. lixula fue estimulado para liberar los gametos tocando la piel con dos electrodos conectados a un transformador de $35 \mathrm{~V}$ (aproximadamente $10 \mathrm{~s}$ cada vez). En los erizos $P$. lividus y $S$. granularis la liberación de gametos fue estimulada con una inyección de $5 \mathrm{~mL}$ de $\mathrm{KCl} 0.5$ $\mathrm{M}$, a través del peristoma dentro de la cavidad celómica. Se utilizaron cuatro réplicas por tratamiento y aproximadamente 400 huevos fertilizados eran introducidos en cada réplica. Los experimentos fueron realizados en una cámara de incubación (ASL-Snijders) con temperatura constante de $20 \pm 0.5^{\circ} \mathrm{C}$ y fotoperiodo de $16 \mathrm{~h} /: 8 \mathrm{~h}$ luz:oscuridad. Los bioensayos finalizaban cuando los embriones de los tubos controles alcanzaban la etapa larval de pluteus con los cuatro brazos totalmente desarrollados, siendo fijado cada tubo con formaldehído tamponado. Los tiempos de exposición variaron de 28 h para $P$. 
constant temperature chamber (ASL-Snijders) at $20 \pm 0.5^{\circ} \mathrm{C}$, with a 16-h/8-h light/dark photoperiod. Tests were finished when control embryos reached fully developed four-arm pluteus larval stage, each test tube being fixed with buffered formalin. The exposure period varied from $28 \mathrm{~h}$ for $P$. lividus to $38 \mathrm{~h}$ for A. lixula and S. granularis. Using a microscope, the first 100 embryos encountered in each tube were counted for normal or abnormal development. Reference toxicant tests were conducted with each batch of organisms using sodium dodecyl sulfide $\left(\mathrm{C}_{12} \mathrm{H}_{25} \mathrm{NaSO}_{4}\right)$. At the beginning and the end of every test, temperature, salinity, dissolved oxygen, $\mathrm{pH}$ and ammonia were measured, to ensure the acceptability of the tests. Sediment-water interface toxicity tests involved wholesediment exposures in 15-mL polystyrene tubes, introducing 2 $\mathrm{mL}$ of whole-sediment sample using a syringe with the head cut-off and $8 \mathrm{~mL}$ of control water (added with care to minimize resuspension), following the procedures of Cesar et al. (2004). Sediments were allowed to settle overnight and a membrane $(0.45 \mu \mathrm{m})$ was placed on the water-sediment interface. Control sediment consisted of commercially, washed, fine-grain, chemically pure sea sand (PANREAC 211160).

Static 10-day exposures with the estuarine amphipods, $M$. gryllotalpa and $S$. sabatieri, were conducted according to methods detailed in the testing manual of the US Environmental Protection Agency (1994). The test chambers consisted of 1-L polyethylene jars. Five replicate test chambers were used per treatment, with each replicate receiving 10 healthy, randomly selected amphipods. After the exposure period at $20 \pm 0.5^{\circ} \mathrm{C}$, the test organisms were sieved from the sediment, and the survivors were transferred into beakers with clean control sediment to count the number of animals that were not able to rebury. The measured endpoints were mortality and sublethal effects, including the inability to rebury and immobilization. Temperature, salinity, dissolved oxygen, $\mathrm{pH}$ and ammonia were measured at the beginning and at the end of the test. During the development of the whole-sediment toxicity test, 48-h water-only reference toxicity tests using sodium dodecyl sulfide were performed to assess the state of health of the field-collected organisms.

\section{Seagrass metal accumulation}

In order to evaluate whether the metal contents in sediments were bioavailable to rooted aquatic plants in the field, we analyzed metal concentrations in the seagrass $C$. nodosa. Sediment and macrophyte samples were collected by snorkel diving. Entire plants and the top $5 \mathrm{~cm}$ of sediments were collected at stations BW, PW, CI and CII, where the phanerogam grows to form seagrass beds. The plant material was placed in clean polythene bags and transported to the laboratory on ice. In the laboratory, phanerogam leaves were scraped with a glass slide to separate the particulate material, extracellular polymeric substances and the epibionts that form the biofilm on the leaf surface. In the rest of the plant tissues, the adhering particulate material and sediments were removed rubbing off lividus a 38 h para A. lixula y S. granularis. Los 100 primeros embriones sacados de cada tubo eran examinados utilizando un microscopio óptico para cuantificar los embriones con desarrollo normal o anormal. Se realizaron bioensayos con sustancias de referencia para valorar la sensibilidad de cada lote de organismos empleando sodio dodecil sulfato $\left(\mathrm{C}_{12} \mathrm{H}_{25} \mathrm{NaSO}_{4}\right)$. $\mathrm{Al}$ inicio y final de cada ensayo se medían temperatura, salinidad, oxígeno disuelto, $\mathrm{pH}$ y amonio para asegurar la aceptabilidad de los ensayos. Los bioensayos de interfase aguasedimento se realizaron en tubos de ensayo de poliestireno de $15 \mathrm{~mL}$, introduciendo $2 \mathrm{~mL}$ de sedimento con una jeringuilla y $8 \mathrm{~mL}$ de agua control, siguiendo el procedimiento descrito por Cesar et al. (2004). Los tubos se dejaban reposar durante toda la noche y se colocaba una malla $(0.45 \mu \mathrm{m})$ en la superficie del sedimento. Se utilizaron sedimentos control que consistían en arena comercial químicamente pura (PANREAC 211160).

Los ensayos de 10 días de duración con los anfípodos M. gryllotalpa y $S$. sabatieri fueron realizados siguiendo los protocolos descritos en el manual de toxicidad del US Environmental Protection Agency (1994). Las cámaras de incubación consistían en recipientes de polietileno de $1 \mathrm{~L}$ en los que se introducían 10 anfípodos seleccionados al azar. Se utilizaron cinco réplicas por cada tratamiento Una vez finalizado el período de exposición a $20 \pm 0.5^{\circ} \mathrm{C}$, los anfípodos eran tamizados y transferidos a otro recipiente con sedimento control para probar si los animales eran capaces de enterrarse de nuevo. La medida final obtenida fue mortalidad junto con efectos subletales como incapacidad para enterrarse o inmovilidad. Se midieron los parámetros de calidad del agua: temperatura, salinidad, oxígeno disuelto, $\mathrm{pH}$ y amonio al inicio y al final de cada ensayo. Durante el desarrollo de los ensayos de toxicidad con sedimento se realizaron bioensayos de $48 \mathrm{~h}$ con agua de referencia utilizando la sustancia de referencia sodio dodecil sulfato (SDS) para evaluar el estado de salud de los anfípodos.

\section{Bioacumulación}

Con el fin de determinar si los metales de los sedimentos se encontraban biodisponibles para las plantas acuáticas, analizamos las concentraciones de metales en la fanerógama marina C. nodosa. Las muestras de sedimentos y plantas fueron recogidas por buceadores, tomando plantas enteras y los $5 \mathrm{~cm}$ superficiales de sedimento en las estaciones donde crece la esta fanerógama (BW, PW, CI y CII). Las muestras vegetales se transportaron con hielo al laboratorio en bolsas de politeno. En el laboratorio, las hojas eran raspadas con un portaobjetos de cristal para separar el material particulado, las substancias poliméricas extracelulares y los epibiontes que forman el biofilm sobre la superficie de las hojas. En el resto de tejidos de la planta, el material particulado adherido y los sedimentos fueron separados frotando los tejidos con un cepillo de dientes blando, posteriormente los tejidos eran lavados con ácido nítrico ultrapuro (aproximadamente al 2\%) y enjuagados con agua destilada. Las plantas eran divididas en las siguientes fracciones: raíces, tallos y hojas. Cada muestra era secada a 
the tissues with a soft toothbrush, washing them with ultrapure nitric acid (approximately 2\%) and then rinsing with distilled water. Plants were divided into the following fractions: roots, rhizomes and leaves. Each sample was dried at $60^{\circ} \mathrm{C}$ until constant weight. Prior to digestion, samples were powdered in a porcelain mortar and homogenized. Digestions were carried out in triplicate on the homogenized total-sediment and plant fraction. About $0.2 \mathrm{~g}$ of sample was digested, adding $1 \mathrm{~mL}$ of a nitric, perchloric and sulphuric acid mixture (8:8:1). Samples were heat-digested by a stepwise increase in temperature to $380^{\circ} \mathrm{C}$ until total evaporation, and then rediluted with deionized water in an ultrasonic bath, acidified with suprapure hydrochloric acid. The concentrations of $\mathrm{Zn}, \mathrm{Pb}$, and $\mathrm{Cd}$ were measured polarographically by anodic stripping voltammetry (Metrohm 646 VA Processor) with hanging mercury drop. Quality assurance procedures included the use of the certified reference material NIST 1577b (bovine liver). Mean recovery for selected metals was higher than $90 \%$.

\section{Physicochemical analyses}

Measurements of pore-water salinity were made using a multiparametric recorder (WTW, MultiLine P4) extracting the interstitial water by sediment centrifugation. Sediment particle size distribution was determined by mechanical dry sieving (Buchanan, 1984). Samples of oven-dried sediments were sieved through a stacked set of graded sieves within the range 2000-62 $\mu \mathrm{m}$. The percentage of organic matter was determined as the percentage of weight lost upon ignition of dry sediment in a muffle furnace $\left(6 \mathrm{~h}\right.$ at $\left.450^{\circ} \mathrm{C}\right)$. The dried sediments were finely ground and carefully sieved through a $63-\mu \mathrm{m}$ stainless steel mesh. Total organic carbon content was determined with an elemental analyzer (Carlo Erba Instruments, EA1108) following sample preparation with $1 \mathrm{~N} \mathrm{HCl}$ to decompose carbonates (Verdardo et al., 1990). Sediment samples for the acid volatile sulfide (AVS) and simultaneously extracted metals (SEM) were frozen without airhead space, to minimize sulfide oxidation. Sediment samples $(n=4)$ were analyzed for AVS by a cold-acid purge-and-trap technique described in detail by Allen et al. (1993). The sediment solid-phase sulfide was converted to hydrogen sulfide by adding hydrochloric acid. The hydrogen sulfide was purged with nitrogen and trapped in a $\mathrm{NaOH}$ solution and determined with an ion selective silver/sulfide electrode (ThermoOrion, model 9616). The sediment-water-hydrochloric acid slurry remaining in the reaction flask was immediately filtered, and $\mathrm{Zn}, \mathrm{Cd}, \mathrm{Pb}$ and $\mathrm{Cu}$ concentrations were measured by anodic stripping voltammetry (Metrohm 646 VA Processor) with hanging mercury drop. This SEM fraction is the most appropriate for evaluating metal/AVS interactions in sediments (Allen et al., 1993).

\section{Benthic community analyses}

Macrobenthic invertebrates were sorted from the sediment with the help of a binocular magnifying glass and classified $60^{\circ} \mathrm{C}$ hasta alcanzar un peso constante. Antes de la digestión, las muestras de tejidos eran pulverizadas en un mortero de porcelana y homogeneizadas. Las digestiones se realizaron por triplicado. Aproximadamente $0.2 \mathrm{~g}$ de muestra eran digeridos, añadiendo $1 \mathrm{~mL}$ de una mezcla de ácidos nítrico, perclórico y sulfúrico (8:8:1). Las muestras eran digeridas en caliente con incrementos de temperatura hasta los $380^{\circ} \mathrm{C}$ hasta la evaporación total, entonces eran rediluidas con agua desionizada en un baño de ultrasonidos y acidificadas con ácido clorhídrico suprapuro. Las concentraciones de $\mathrm{Zn}, \mathrm{Pb}$ y Cd eran analizadas polarográficamente con un voltamperímetro de gota de mercurio (Metrohm 646 VA Processor). Los procedimientos para asegurar la calidad de los análisis incluían el uso de material de referencia certificado NIST 1577b. Para los metales seleccionados el porcentaje de recuperación fue mayor del 90\%.

\section{Análisis fisicoquímicos}

Las medidas de la salinidad del agua intersticial fueron realizadas utilizando una sonda multiparamétrica (WTW, MultiLine P4) una vez extraída el agua intersticial del sedimento por centrifugación. La granulometría del sedimento fue determinada tamizando el sedimento a través de una serie de tamices dentro del intervalo 2000-62 $\mu \mathrm{m}$ (Buchanan, 1984). El contenido en materia orgánica fue determinado como el porcentaje de pérdida de peso del sedimento seco al introducirlo en un horno $6 \mathrm{~h}$ a $450^{\circ} \mathrm{C}$. El sedimento seco era tamizado a través de una malla $63 \mu \mathrm{m}$ para determinar el carbono orgánico total (TOC) con un analizador elemental Carlo Erba Instruments (EA1108) después de un tratamiento de la muestra con HCl $1 \mathrm{~N}$ para eliminar los carbonatos (Verdardo et al., 1990). Las muestras de sedimento, para la determinación simultánea de los sulfuros ácidos volátiles (AVS) y los metales (SEM), fueron congeladas sin aire para minimizar la oxidación de los sulfuros. Las muestras de sedimento $(n=4)$ fueron analizadas para AVS utilizando un destilador con ácido según la técnica descrita en detalle por Allen et al. (1993). Los sulfuros de los sedimentos eran transformados en sulfuro de hidrógeno al añadir ácido hidroclórico $6 \mathrm{M}$ al recipiente de reacción. El sulfuro de hidrógeno era purgado con nitrógeno y atrapado en una solución $\mathrm{NaOH} 2 \mathrm{M}$. La cantidad de sulfuro fue determinada con la ayuda de un electrodo de ión selectivo plata/sulfuro (ThermoOrion, modelo 9616). El líquido ácido que permanecía en el recipiente de reacción era filtrado inmediatamente y las concentraciones de $\mathrm{Zn}, \mathrm{Pb}$ y $\mathrm{Cd}$ fueron determinadas por voltametría de ánodo con gota de mercurio (Metrohm 646 VA Processor). Esta fracción SEM es la más apropiada para evaluar las interacciones metal/AVS en los sedimentos (Allen et al., 1993).

\section{Análisis de las comunidades bentónicas}

Los macroinvertebrados fueron separados del sedimento con la ayuda de una lupa binocular. La fauna, una vez separada, fue clasificada y preservada en alcohol al 70\%. Las 
into major constituent taxa. Taxonomic identifications were then performed to the lowest possible level. The structure of the benthic community was analyzed in terms of species composition and abundance, diversity and evenness. The following descriptive community parameters were calculated for each sample $(n=4)$ and then summarized for each station: total abundance, species richness (Margelef's d), Shannon-Wiener diversity $\left(\log _{2}, \mathrm{H}^{\prime}\right)$, evenness (Pielou's J) and Simpson's dominance index (S). The numerical contribution of major taxonomic groups (Polychaeta, Mollusca, Crustacea) was calculated as the proportion of abundance of a taxon to total abundance for each sample and station; mean proportions were also determined and expressed as percentages.

\section{Data analyses}

Data from the toxicity tests, expressed as percentage of amphipod survival and normally-developed sea urchin larvae, were analyzed using the Toxstat $^{\circledR}$ V.3.3 statistical program (Gulley et al., 1991). Sea urchin results were arc sine root transformed prior to statistical analysis. Data were analyzed for normality and homogeneity of variances with Shapiro-Wilk's test and Hartley's test, respectively. Once data passed these tests, they were subjected to Dunnet's test (ANOVA, $P<0.05$ ). The $\mathrm{EC}_{50}-48 \mathrm{~h}$ values for the amphipod sensitivity tests were calculated with the statistical program Trimmed SpearmanKarmber, applying Abbott's correction (Hamilton et al., 1977). The $\mathrm{IC}_{50}$ values for the sea urchin reference toxicant test were estimated with the ICp method (US Environmental Protection Agency, 1993). Data from the seagrass bioaccumulation were $\log$ transformed and later subjected to Dunnet's test (ANOVA, $P<0.05)$ to check differences in metal accumulation between stations.

The survival in toxicity bioassays and field abundance of S. sabatieri were correlated by the Spearman correlation analysis. The descriptive analyses applied to the infaunal data and the multivariate analyses were performed using the PRIMER (Plymouth Routines in Multivariate Ecological Research, v5) software package (Clarke and Gorley, 2001; Clarke and Warwick, 2001). In order to determine faunal similarities between stations, further comparisons were made using a multivariate ordination technique: non-metric multidimensional scaling (MDS) based on the pooled data with the Bray-Curtis similarity index (Clarke, 1993).

Bray-Curtis similarity matrices were derived using fourth root transformation to absolute abundance data. MDS was used to derive a two-dimensional ordination of sites. Associations between environmental variables and patterns of multivariate community composition were explored using the BIOENV procedure (Somerfield et al., 1994), which exhaustively searches for the combination of environmental variables that produces the similarity matrix most highly correlated to the similarity matrix of sites based on the biota. Environmental identificaciones taxonómicas se realizaron al nivel más bajo posible. La estructura de las comunidades bentónicas fue analizada en términos de composición de especies y abundancia, diversidad y equitatividad. Se calcularon los siguiente parámetros descriptivos de la comunidad para cada muestra $(n=4)$, resumiéndolos para cada estación: abundancia total, riqueza de especies (índice de Margelef, d), diversidad de ShannonWiener ( $\left.\log _{2}, H^{\prime}\right)$, equitatividad (índice de Pielou, J) y el índice de dominancia de Simpson (S). La contribución numérica de los mayores grupos taxonómicos (poliquetos, moluscos y crustáceos) fue calculada como la proporción de abundancia de un taxón entre la abundancia total de la muestra y la estación; las proporciones medias fueron también determinadas y expresadas como porcentajes.

\section{Análisis de los datos}

Los datos de los ensayos de toxicidad, expresados como porcentaje de supervivencia de anfípodos y larvas de erizos normalmente desarrollados, fueron analizados utilizando el programa estadístico Toxstat ${ }^{\circledR}$ V.3.3 (Gulley et al., 1991). Los resultados de los ensayos de erizos eran transformados aplicando el arco seno de la raíz cuadrada antes del análisis estadístico. Los datos fueron analizados para comprobar su normalidad y homogeneidad de varianza con los tests de Shapiro-Wilk y Hartley respectivamente. Una vez que los datos pasaban las pruebas mencionadas, éstos eran posteriormente sometidos a un test de Dunnet (ANOVA, $P<0.05$ ). Los valores $\mathrm{EC}_{50}-48 \mathrm{~h}$ para los ensayos de sensibilidad con anfípodos fueron calculados con el programa estadístico Trimmed Spearman-Karmber, aplicando la corrección de Abbott (Hamilton et al., 1977). Los valores IC $_{50}$ para los ensayos con erizos con sustancia de referencia fueron estimados con el método ICp (US Environmental Protection Agency, 1993). Los datos de bioacumulación en la planta fueron logarítmicamente transformados y posteriormente sometidos al test de Dunnet (ANOVA, $P<0.05$ ) para determinar diferencias en la acumulación de metales entre estaciones.

Los bioensayos de toxicidad y las abundancias encontradas del anfípodo $S$. sabatieri en las estaciones de muestreo fueron correlacionadas mediante un análisis de correlaciones de Spearman. Los análisis descriptivos y los multivariantes aplicados a la fauna bentónica fueron realizados utilizando el programa estadístico PRIMER (Plymouth Routines in Multivariate Ecological Research, v5) (Clarke y Gorley, 2001; Clarke y Warwick, 2001). Con el propósito de investigar las similitudes faunísticas entre estaciones se utilizó una técnica de ordenación multivariante no paramétrica (MDS) basada en la matriz de datos originales a la que se había calculado el índice de similitud de Bray-Curtis (Clarke, 1993). Las matrices de similitud de Bray-Curtis fueron obtenidas de los datos originales, mismos que se transformaron a raíz cuarta. Para producir una ordenación en dos dimensiones de las estaciones de estudio se utilizó el MDS. Las asociaciones entre variables ambientales y los patrones de la composición multivariante de 
similarity matrices were calculated using normalized Euclidian distance and correlations were calculated using the harmonic Spearman rank correlation coefficient.

Multivariate relationships between the sediment physicochemical parameters were evaluated using correlation-based principal components analysis (PCA). Associations were evaluated between the eight sediment physicochemical variables (fine fraction, organic matter, total organic carbon content, and $\mathrm{Zn}, \mathrm{Pb}, \mathrm{Cu}, \mathrm{Cd}$ and AVS concentrations). A component loading cut-off of 0.40 was used to select variables for inclusion in factors, based on suggestions by Tabachnick and Fidell (1996).

\section{Results}

\section{Toxicity}

\section{Sea urchins}

The embryo-larval bioassays showed consistent and similar patterns of toxicity between the three equinoderm species employed. The results, summarized in figure 2, show that, except for $S$. granularis at station CI , all stations presented significant differences (Dunnet's test, $P<0.05$ ) from the reference for all three species of sea urchins. The results indicated toxicity moving from the sediments to the water column, with consequent adverse effects on sea urchin embryo development. Generally, S. granularis was the species that presented the highest percentage of normally-developed pluteus larvae at

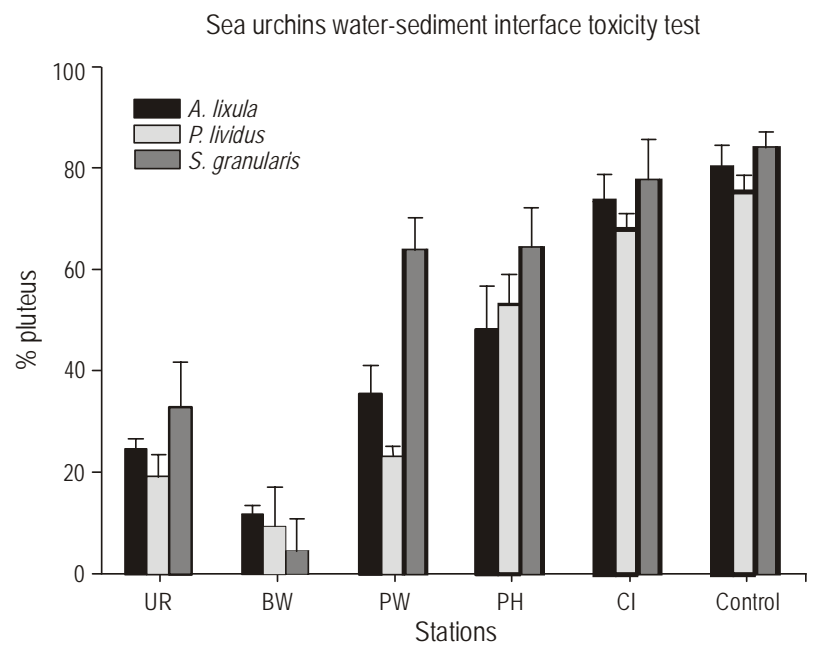

Figure 2. Percentage of normal pluteus larvae (\% pluteus) of the sea urchins Arbacia lixula, Paracentrotus lividus and Sphaerechinus granularis in water-sediment interface toxicity tests. The control sediment consisted of commercial, washed, fine-grain, chemically pure sea sand (PANREAC 211160).

Figura 2. Porcentaje de larvas pluteus normalmente desarrolladas (\% pluteus) de los erizos Arbacia lixula, Paracentrotus lividus y Sphaerechinus granularis en las pruebas de toxicidad con la interfase agua-sedimento. El sedimento control consistió en arena de mar comercial de grano fino, lavada, químicamente pura (PANREAC 211160). la comunidad fueron explorados utilizando el procedimiento BIOENV (Somerfield et al., 1994), el cual busca exhaustivamente la combinación de variables ambientales que produzca la matriz de similitud más altamente correlacionada con la matriz de similitud de los sitios basados en la biota. Las matrices de similitud ambiental fueron calculadas utilizando distancias Euclídeanas normalizadas y las correlaciones empleando el coeficiente de correlación armónico de Spearman.

Las relaciones multivariantes entre los parámetros físicoquímicos del sedimento fueron evaluadas utilizando un análisis de componentes principales (PCA). Las asociaciones fueron evaluadas entre las ocho variables físico-químicas del sedimento (fracción de finos, materia orgánica, contenido de carbono orgánico y concentraciones de $\mathrm{Zn}, \mathrm{Pb}, \mathrm{Cu}, \mathrm{Cd}$ y AVS). Se utilizó un componente de corte de 0.40 para seleccionar las variables para la inclusión en factores basándose en las recomendaciones de Tabachnick y Fidell (1996).

\section{Resultados}

\section{Toxicidad}

Erizos

Los bioensayos de toxicidad con erizos presentaron resultados similares con las tres especies empleadas. Todas las estaciones, excepto la CI para $S$. granularis, presentaron diferencias significativas (test de Dunnet, $P<0.05$ ) con respecto a la estación de referencia. Estos resultados indican que la toxicidad de los sedimentos pasa a la columna de agua afectando negativamente a los embriones de erizos. Generalmente $S$. granularis fue la especie que presentó mayor porcentaje de larvas pluteus normalmente desarrolladas en cada estación. La $\mathrm{IC}_{50}$ para $A$. lixula, $P$. lividus y $S$. granularis en los tests de sensibilidad con SDS fue de $1.63 \mathrm{mg} \mathrm{L}^{-1}$ ( \pm SD 0.23), $1.71 \mathrm{mg} \mathrm{L}^{-1}$ ( \pm SD 0.28$)$ y $1.87 \mathrm{mg} \mathrm{L}^{-1}$ ( \pm SD 0.01 ) respectivamente, concentraciones similares a las encontradas por Cesar et al. (2002).

\section{Anfípodos}

Los bioensayos con sedimento empleando ambas especies de anfípodos presentaron patrones de toxicidad similares entre sí y a los obtenidos con los bioensayos con larvas de erizos. Todas las estaciones, excepto la Isla del Ciervo (CI), presentaron diferencias significativas con respecto a la estación de referencia (test de Dunnet, $P<0.05$ ). Para $M$. gryllotalpa el porcentaje medio de mortalidad durante los 10 días de duración del test osciló entre 2-8\% en las estaciones CI y de referencia, y $46-54 \%$ en las estaciones PW y BW (fig. 3). El máximo porcentaje de mortalidad para el anfípodo $S$. sabatieri fue registrado en la estación BW (88\%). EL valor medio de la concentración de efecto $\left(\mathrm{EC}_{50}\right)$ en las pruebas con tóxico de referencia empleando SDS fue de $2.98 \mathrm{mg} \mathrm{L}^{-1}$ ( \pm SD 0.26) para 
every station. The $50 \%$ inhibiting concentrations $\left(\mathrm{IC}_{50}\right)$ for $A$. lixula, P. lividus and S. granularis in the reference toxicity tests with sodium dodecyl sulfide were $1.63 \mathrm{mg} \mathrm{L}^{-1}$ ( \pm SD 0.23 ), $1.71 \mathrm{mg} \mathrm{L}^{-1}( \pm \mathrm{SD} 0.28)$ and $1.87 \mathrm{mg} \mathrm{L}^{-1}( \pm \mathrm{SD} 0.01$ ), respectively, similar concentrations to those obtained by Cesar et al. (2002).

\section{Amphipods}

Whole-sediment bioassays with both species of amphipods showed similar toxicity patterns to those obtained with equinoderm embryo-larval bioassays. All stations, except for El Ciervo Island (CI), presented significant differences (Dunnet's test, $P<0.05)$ from the reference for both species of amphipods. For M. gryllotalpa, the mean percentage of amphipod mortality during the 10-day amphipod toxicity test ranged from $2-8 \%$ in the reference and CI stations to $46-54 \%$ at stations PW and BW (fig. 3). For S. sabatieri, the maximum percentage of amphipod mortality (88\%) was observed at station BW. The effect concentration $\left(\mathrm{EC}_{50}\right)$ mean value for the 48 -h wateronly reference toxicant tests with sodium dodecyl sulfide was $2.98 \mathrm{mg} \mathrm{L}^{-1}$ ( \pm SD 0.26 ) for M. gryllotalpa, similar to that found by other authors (Cesar et al., 2000, 2002) and to that obtained for $S$. sabatieri, which presented a mean $\mathrm{EC}_{50}$ value of $3.10 \mathrm{mg} \mathrm{L}^{-1}$ ( \pm SD 0.09 ).

\section{Seagrass metal accumulation}

Cymodocea nodosa plants collected from the Mar Menor lagoon contained $\mathrm{Zn}, \mathrm{Pb}$ and $\mathrm{Cd}$, indicating their bioavailability to rooted aquatic plants. The metal concentrations in roots, rhizomes, leaves and leaf-biofilm are represented together with total sediment metal concentrations (fig. 4). There were significant differences (Dunnet's test, $P<0.05$ ) in each plant fraction metal concentration between sampling stations. Stations BW and PW located at the outlets of both desert streams presented the highest metal contents in sediments and in the different plant fractions analyzed, the former being the station that showed the highest concentrations. Both reference stations (CI and CII) presented similar metal concentrations in the different plant fractions analyzed. Except for station BW, where the $\mathrm{Pb}$ concentration was higher in roots than in the surrounding sediment, the metal concentrations determined in the sediments were higher than in the plant fractions (leaves, rhizomes and roots) for the three metals determined. The highest metal concentrations in plants from polluted stations were found in the leaf biofilm (3913 $\pm 326 \mu \mathrm{g} \mathrm{Zn} / \mathrm{g}$ d.w. and $1568 \pm 191 \mathrm{mg} \mathrm{Pb} / \mathrm{g}$ d.w. for station BW, and $12489 \pm 2592 \mathrm{ng} \mathrm{Cd} / \mathrm{g}$ d.w. for station $\mathrm{PW}$ ), possibly due to its ability to form complexes between metals and the extracellular polymeric substances that form the biofilm.

Different patterns were observed in plant metal concentrations between both wadis stations (BW and PW) for all three

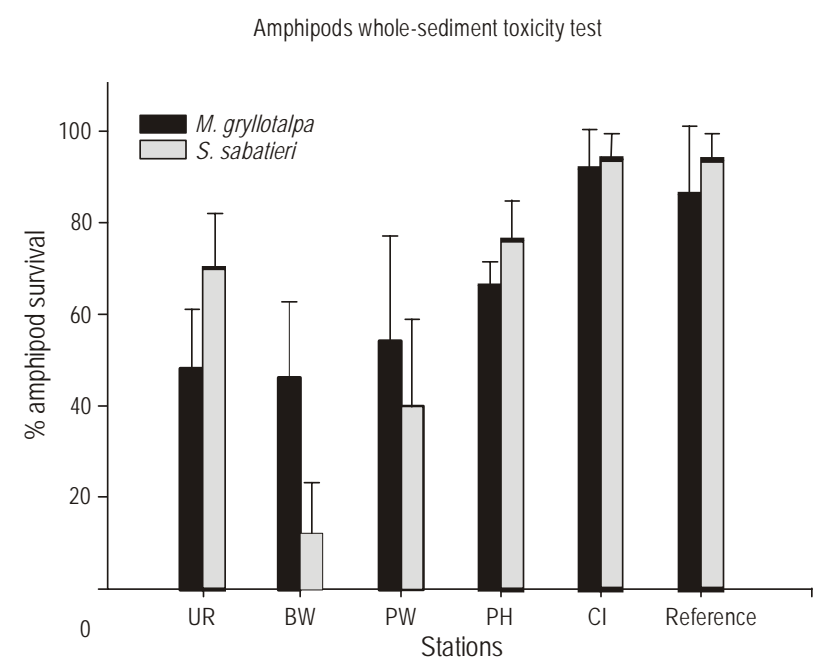

Figure 3. Percentage of survival of the amphipods Microdeutopus gryllotalpa and Siphonoecetes sabatieri in whole-sediment toxicity tests. Reference stations correspond to the amphipod collection site.

Figura 3. Porcentaje de supevivencia de los anfípodos Microdeutopus gryllotalpa y Siphonoecetes sabatieri en las pruebas de toxicidad con sedimento. Las estaciones de referencia corresponden con el lugar de recolección de los anfípodos.

M. gryllotalpa, similar a lo obtenido por otros autores (Cesar et al., 2000, 2002) con esta misma especie y a lo obtenido con S. sabatieri, el cual mostró $\mathrm{EC}_{50}$ medio de $3.10 \mathrm{mg} \mathrm{L}^{-1}( \pm \mathrm{SD}$ 0.09).

\section{Bioacumulación}

Las plantas de $C$. nodosa recogidas del Mar Menor contenían $\mathrm{Zn}, \mathrm{Pb}$ y $\mathrm{Cd}$ indicando la biodisponibilidad de los mismos para plantas acuáticas. Las concentraciones de metales en raíces, tallos, hojas y en el biofilm de las hojas, están representadas junto con las concentraciones totales en los sedimentos, en la figura 4. Las concentraciones de metales en cada fracción de la planta presentaron diferencias significativas (test de Dunnet, $P<0.05$ ) entre las estaciones muestreadas. Las estaciones BW y PW, localizadas en la desembocadura de ambas ramblas, presentaron los mayores contenidos de metales en sedimentos y en las fracciones de la planta analizadas, siendo BW la estación que presentó los mayores valores. Ambas estaciones de referencia (CI y CII) presentaron concentraciones de metales similares en cada fracción de planta analizada. A excepción de la estación BW, donde la concentración de plomo fue mayor en las raíces que en los sedimentos, las concentraciones de metales determinadas en los sedimentos fueron mayores que en las fracciones de la planta (hojas, tallos y raíces) para los tres metales analizados. La mayor concentraciones de metales en las plantas de las estaciones contaminadas fue encontrada en el biofilm de las hojas (3913 $\pm 326 \mathrm{mg} \mathrm{Zn/g}$ p.s. y $1568 \pm 191 \mathrm{mg}$ Pb/g p.s. para la estación BW, y $12489 \pm$ 2592 ng Cd/g p.s. en la estación PW), posiblemente debido a su habilidad para formar complejos entre los metales y los polímeros extracelulares que forman el biofilm. 
metals studied, the highest plant metal content being found in the roots from station BW, but in the leaves from station PW. The metal content in the rhizomes was lower than in the leaves and roots for every station and metal studied.
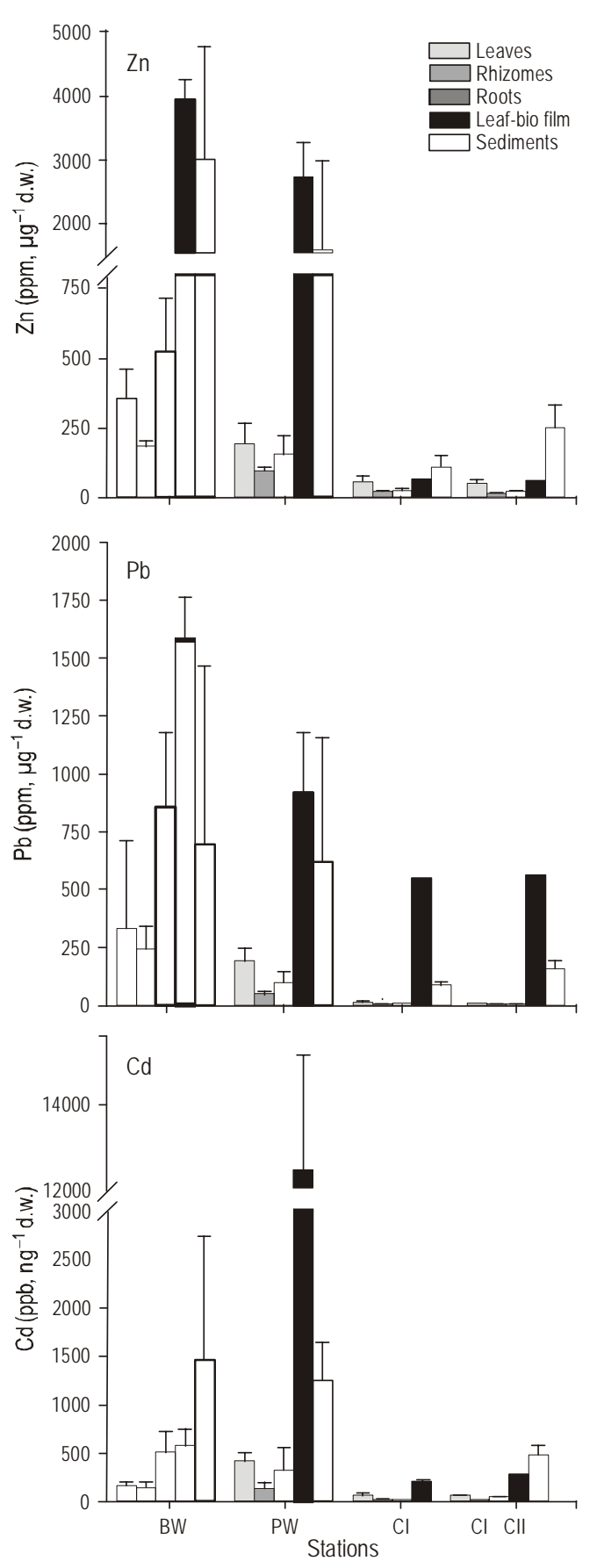

Figure 4. Concentration of $\mathrm{Zn}, \mathrm{Pb}$ and $\mathrm{Cd}$ in different fractions of Cymodocea nodosa (roots, rhizomes, leaves and leaf-biofilm) and total concentration in sediments.

Figura 4. Concentración de $\mathrm{Zn}, \mathrm{Pb}$ y $\mathrm{Cd}$ en diferentes fracciones de Cymodocea nodosa (raíces, tallos, hojas y biofilm de las hojas) y concentración total en sedimentos.
Para los tres metales estudiados se observaron patrones diferentes en las concentraciones de metales entre ambas estaciones de las ramblas (BW y PW); el mayor contenido en metales de la planta fue encontrado en las raíces de la estación BW, mientras que en la estación PW éste correspondía a las hojas. La concentración de metales en los tallos fue menor que en hojas y raíces para todas las estaciones y metales investigados.

\section{Análisis fisicoquímicos}

Los análisis granulométricos mostraron que los sedimentos estaban principalmente compuestos por arenas finas (tabla 1). La estación BW, localizada en la desembocadura de la rambla del Beal, presentó los contenidos más altos en limos y arcillas (10.5\%), con un porcentaje similar a la estación CII (8.4\%). La materia orgánica varió entre $2.23 \%$ y $8.17 \%$ del sedimento seco en las estaciones $\mathrm{PH}$ y BW, respectivamente, presentando esta última el contenido en carbono orgánico más alto. La estación BW presentó los mayores niveles de metales en los sedimentos medidos de forma simultánea a los sulfuros; sin embargo, la mayor concentración de AVS fue observada en la estación PW. La relación SEM-AVS fue positiva en PH, UR, PW y BW, siendo acusadamente mayor en esta última estación. Las estaciones CI, CII y la estación de referencia presentaron valores negativos.

La aplicación del análisis PCA a las variables del sedimento identificó tres nuevas variables o factores principales que explicaron $90.7 \%$ de la varianza en los datos originales. La primera variable, PC1, fue predominante y abarcó $47.5 \%$ de la varianza. Este factor combinaba las concentraciones de $\mathrm{Zn}, \mathrm{Pb}$, materia orgánica y contenido en limos-arcillas del sedimento. La segunda variable, PC2, abarcó $29.4 \%$ de la varianza y combinaba las concentraciones de $\mathrm{Cu}$ y $\mathrm{Cd}$ extraídos de forma simultánea a los sulfuros. La tercera variable, PC3, abarcó el $13.8 \%$ de la varianza y era una combinación de AVS y el contenido en carbón orgánico.

El gráfico en dos dimensiones del PCA está representado en la figura 5, con las estaciones ordenadas a lo largo del primer eje según las concentraciones de $\mathrm{Zn}$ y $\mathrm{Pb}$, la materia orgánica y el contenido en finos. Todas las muestras de la estación BW presentaron valores de PC1 mayores a 3.5, lo que indica que se encuentran severamente contaminadas con cinc y plomo, y que también presentan un alto contenido en sedimentos finos y materia orgánica.

Las estaciones CI y CII presentaron valores de PC1 y PC2 cercanos a 0, señalando niveles de metales bajos o moderados. Sin embargo, las estaciones BW, PW y UR, con puntuaciones PC2 entre 1 y 2 tuvieron niveles moderados de $\mathrm{Cu}$ y Cd. Los resultados del análisis PCA estuvieron en correspondencia con los obtenidos en la ordenación del análisis MDS.

\section{Análisis de las comunidades bentónicas}

Los resultados de los análisis descriptivos se presentan en la tabla 2, junto con la contribución numérica de los mayores 
Table 1. Summary of sediment physicochemical analyses: pore-water salinity, percentage of fine sediments (<63 $\mu \mathrm{m})$, percentage of organic matter (OM), percentage of total organic carbon (TOC), concentration of metals extracted simultaneously to sulfides ( $\mathrm{Zn}, \mathrm{Pb}, \mathrm{Cu}$ and $\mathrm{Cd}$ ), total of simultaneously extracted metals (SEM), acid volatile sulfide content (AVS) and the SEM-AVS molar difference (concentrations in $\mu \mathrm{mol} \mathrm{g}^{-1} \mathrm{dry}_{\text {sediment). }}$

Tabla 1. Resumen de los análisis fisicoquímicos del sedimento: salinidad del agua intersticial, porcentaje de sedimentos finos ( $<63 \mu \mathrm{m})$, porcentaje de materia orgánica (OM), porcentaje de carbono orgánico total (TOC), concentración de metales extraídos simultáneamente a los sulfuros (Zn, Pb, Cu y Cd), metales totales simultaneamente extraídos (SEM), contenido en sulfuros ácidos volátiles (AVS) y la diferencia molar SEM-AVS (concentraciones en $\mu$ mol $\mathrm{g}^{-1}$ sedimento seco).

\begin{tabular}{lccccccc}
\hline $\begin{array}{l}\text { Sediment physico- } \\
\text { chemical parameters }\end{array}$ & UR & BW & PW & PH & CI & CII & $\begin{array}{c}\text { Reference } \\
\text { (Encañizadas) }\end{array}$ \\
\hline Pore-water salinity (psu) & $46.2 \pm 0.5$ & $46 \pm 0.7$ & $45.4 \pm 0.9$ & $46.2 \pm 0.5$ & $45.5 \pm 0.7$ & $46 \pm 0.3$ & $43 \pm 1.2$ \\
$<63 \mu \mathrm{m}(\%)$ & $0.4 \pm 0.19$ & $10.5 \pm 5.29$ & $0.6 \pm 0.10$ & $0.2 \pm 0.12$ & $0.16 \pm 0.02$ & $8.4 \pm 0.57$ & $3.8 \pm 0.09$ \\
OM (\%) & $3.08 \pm 0.17$ & $8.17 \pm 0.32$ & $2.43 \pm 0.41$ & $2.23 \pm 0.08$ & $3.17 \pm 0.14$ & $3.05 \pm 0.03$ & $4.99 \pm 0.19$ \\
TOC (\%) & $0.85 \pm 0.03$ & $1.60 \pm 0.24$ & $1.38 \pm 0.05$ & $0.90 \pm 0.01$ & $1.16 \pm 0.08$ & $1.29 \pm 0.61$ & $1.51 \pm 0.07$ \\
$\mathrm{Zn}$ & $6.37 \pm 1.09$ & $62.07 \pm 4.36$ & $4.12 \pm 0.43$ & $0.81 \pm 0.02$ & $1.14 \pm 0.14$ & $0.97 \pm 0.23$ & $0.01 \pm 0.004$ \\
$\mathrm{~Pb}$ & $6.62 \pm 0.21$ & $45.98 \pm 13.1$ & $1.25 \pm 0.15$ & $1.21 \pm 0.09$ & $0.29 \pm 0.01$ & $0.25 \pm 0.04$ & $0.007 \pm 0.002$ \\
$\mathrm{Cu}$ & $0.06 \pm 0.02$ & $0.55 \pm 0.02$ & $0.18 \pm 0.02$ & $0.02 \pm 0.003$ & $0.02 \pm 0.004$ & $0.03 \pm 0.01$ & $0.15 \pm 0.06$ \\
$\mathrm{Cd}$ & $0.01 \pm 0.001$ & $0.02 \pm 0.01$ & $0.005 \pm 0.001$ & $0.002 \pm 0.0$ & $0.003 \pm 0.001$ & $0.004 \pm 0.001$ & $0.005 \pm 0.0$ \\
$\mathrm{SEM}$ & $13.04 \pm 1.02$ & $108.62 \pm 4.36$ & $5.56 \pm 0.51$ & $2.04 \pm 0.10$ & $1.46 \pm 0.14$ & $1.26 \pm 0.27$ & $0.17 \pm 0.01$ \\
$\mathrm{AVS}$ & $1.48 \pm 0.67$ & $2.44 \pm 2.72$ & $5.46 \pm 1.10$ & $0.50 \pm 0.03$ & $1.47 \pm 0.33$ & $2.83 \pm 0.97$ & $0.55 \pm 0.03$ \\
SEM-AVS & $11.57 \pm 0.80$ & $106.18 \pm 5.18$ & $0.10 \pm 0.08$ & $1.54 \pm 0.14$ & $-0.02 \pm 0.02$ & $-1.58 \pm 0.78$ & $-0.38 \pm 0.54$ \\
\hline
\end{tabular}

Physicochemical analyses

The granulometric analysis indicated that sediments are mainly composed of very fine sands (table 1). Station BW located at the mouth of Beal wadi presented the highest content of fine-grained sediments, the percentage of silt-clay (10.5\%) being similar to that of station CII (8.4\%). The organic matter analysis ranged from $2.23 \%$ to $8.17 \%$ of dry sediment for stations $\mathrm{PH}$ and $\mathrm{BW}$, respectively, the higher organic carbon content corresponding to the latter station.

Station BW presented the highest sediment metal values for the metals analyzed simultaneously to sulfides, whereas the highest AVS concentration was observed at station PW. The SEM-AVS relation was positive at $\mathrm{PH}, \mathrm{UR}, \mathrm{PW}$ and BW, being highest in the last station. Negative values were found at CI, CII and the reference station.

The application of factor analysis to the sediment variables identified three new variables or principal factors, which explained $90.7 \%$ of the variance in the original data set. The first new variable, PC1, was predominant and accounted for $47.5 \%$ of the variance. This factor combined the chemical concentrations of $\mathrm{Zn}, \mathrm{Pb}$, organic matter and silt-clay content. The second new variable, PC2, accounted for $29.4 \%$ of the variance and combined the concentration of $\mathrm{Cu}$ and $\mathrm{Cd}$ simultaneously extracted to sulfides. The third new variable, PC3, accounted for $13.8 \%$ of the variance and was a combination of the AVS sediment concentration and the total organic carbon content.

The two-dimensional PCA plot is represented in figure 5, with the stations ordered along the first axis, according to $\mathrm{Zn}$ grupos taxonómicos. Los poliquetos constituyeron el grupo taxonómico dominante en las estaciones próximas a las ramblas (BW y $\mathrm{PW}$ ), mientras que en las estaciones más alejadas (CI, CII y PH) los crustáceos fueron los predominantes. La especie más abundante fue el anfípodo S. sabatieri, seguido de los poliquetos de la familia Cirratulidae, los bivalvos Cerastoderma edule y Mytilaster minimus, y el isópodo Sphaeroma serratum. En general todas las muestras del Mar Menor contuvieron un bajo número de especies, presentando

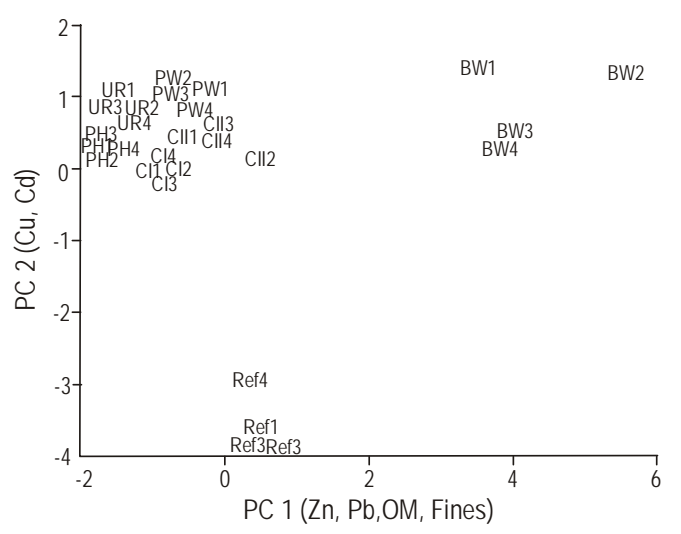

Figure 5. Principal component analysis (PCA) plot for stations UR, BW, PW, $\mathrm{PH}, \mathrm{Cl}, \mathrm{Cll}$ and Ref (Las Encañizadas): 1, 2, 3 and 4 indicate the number of replicate samples for each station.

Figura 5. Gráfico del análisis de componentes principales (PCA) para las estaciones UR, BW, PW, PH, Cl, Cll y Ref (Las Encañizadas): 1, 2, 3 y 4 indican el número de la réplica para cada estación. 
and $\mathrm{Pb}$ concentrations and organic matter and fine sediment content. All the samples from BW had PC1 scores greater than 3.5, suggesting that they are severely contaminated by Zn and $\mathrm{Pb}$; they also presented a high content of fine-grained sediment and organic matter. Stations CI and CII presented PC1 and PC2 values close to 0 , indicating low or moderate levels of metals; however, stations BW, PW and UR, with PC2 scores of between 1 and 2, had moderate contamination levels of $\mathrm{Cu}$ and $\mathrm{Cd}$. The results of the PCA analysis are in accordance with those obtained in the MDS ordination.

\section{Benthic community analyses}

The results of the descriptive analyses are shown in table 2, together with the numerical contribution of the major taxonomic groups. Polychaetes dominated at the stations affected by the discharge of the desert streams (BW and PW), while crustaceans predominated at those stations furthest from the wadis (CI, CII and PH). The amphipod S. sabatieri presented the highest abundance. Other less abundant organisms were the Cirratulidae polychaetes, the bivalves Cerastoderma edule and Mytilaster minimus, and the isopod Sphaeroma serratum.

Biological communities of the Mar Menor lagoon are composed of a low number of marine species and, typically, all the stations exhibited low diversity. Stations CI and CII presented the highest number of species, although station CI showed the lowest diversity and evenness values and the highest dominance due to the high abundance of the amphipod Siphonoecetes sabatieri.

The two-dimensional MDS ordination (fig. 6), based on invertebrate community composition, produced three groups of sites (Bray Curtis similarity between groups of approximately 45\%). One group contained the stations CI, CII and PH, within which replicates were consistently grouped, except replicate CII3 plotted outside the group. Another group included the four replicates of station UR, and a third group consisted of the two flood-way stations (BW and PW), whose replicates were mixed and dispersed to the right side of the plot, presenting the highest variability among replicates. una baja diversidad. Las estaciones CI y CII exhibieron el mayor número de especies, aunque la estación CI presentó los valores de diversidad y equitatividad más bajos y la más alta domin-ancia debido a la alta densidad del anfípodo Siphonoecetes sabatieri.

El análisis MDS (fig. 6), basado en la composición de las comunidades de invertebrados, ordenó las estaciones en tres grandes grupos (similitud Bray Curtis entre grupos de aproximadamente 45\%). El primer grupo contuvo las estaciones CI, CII y PH, cuyas réplicas se encontraron consistentemente agrupadas, excepto CII3 representada fuera del grupo. El segundo grupo incluyó las cuatro réplicas de la estación UR, y el tercer grupo estuvo compuesto por las estaciones de las ramblas (BW y PW) cuyas réplicas se encontraban mezcladas y dispersas en el lado derecho del gráfico, presentando la mayor variabilidad entre réplicas.

El análisis BIOENV obtuvo correlaciones óptimas entre las ocho variables y la matriz biótica. Las variables relacionadas con las concentraciones de metales en los sedimentos fueron

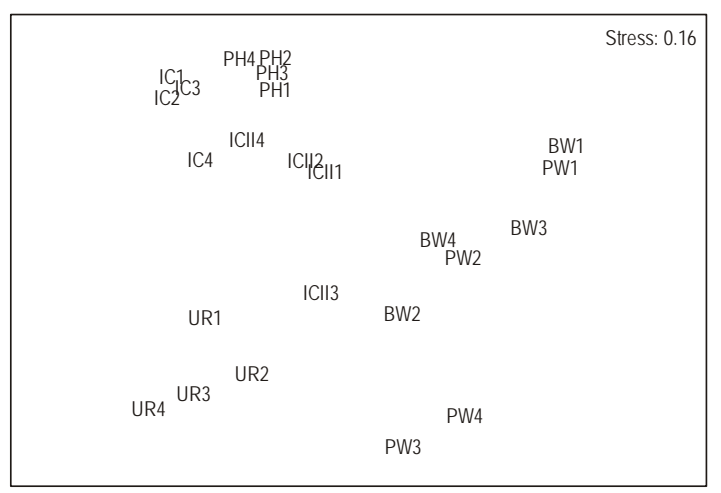

Figure 6. Multidimensional scaling (MDS) ordination plot of benthic fauna abundance data for stations UR, BW, PW, PH, Cl and CII: 1, 2, 3 and 4 indicate the number of replicate samples for each station.

Figura 6. Gráfico de ordenación MDS en dos dimensiones de los datos de abundancia de fauna bentónica para las estaciones UR, BW, PW, PH, Cl y CII: 1, 2, 3 y 4 indican el número de la réplica para cada estación.

Table 2. Mean values of the descriptive parameters for benthic communities at different stations.

Tabla 2. Valores medios de los parámetros descriptivos de las comunidades bentónicas.

\begin{tabular}{lcccccc}
\hline Parameter & UR & BW & PW & PH & CI & CII \\
\hline Number of species & $7 \pm 3$ & $4 \pm 1$ & $7 \pm 4$ & $5 \pm 2$ & $9 \pm 2$ & $11 \pm 2$ \\
Richness (Margalef, d) & $1.81 \pm 0.16$ & $1.10 \pm 0.56$ & $1.77 \pm 1.03$ & $0.63 \pm 0.41$ & $1.42 \pm 0.33$ & $2.31 \pm 0.14$ \\
Diversity (Shannon-Wiener, H') & $1.52 \pm 0.08$ & $1.03 \pm 0.57$ & $1.24 \pm 0.73$ & $0.50 \pm 0.12$ & $0.31 \pm 0.22$ & $1.31 \pm 0.34$ \\
Evenness (Pielou, J) & $0.80 \pm 0.07$ & $0.71 \pm 0.27$ & $0.62 \pm 0.21$ & $0.39 \pm 0.12$ & $0.14 \pm 0.10$ & $0.55 \pm 0.18$ \\
Dominance (Simpson, S) & $0.28 \pm 0.04$ & $0.46 \pm 0.29$ & $0.47 \pm 0.06$ & $0.74 \pm 0.06$ & $0.89 \pm 0.09$ & $0.47 \pm 0.16$ \\
\% Crustacea & 35.8 & 6.9 & 11.6 & 94.4 & 66.1 & 84.8 \\
\% Mollusca & 54.5 & 13.4 & 9.7 & 2.1 & 2.3 & 5.05 \\
\% Polychaeta & 9.8 & 79.7 & 78.7 & 3.5 & 25.2 & 13.40 \\
\hline
\end{tabular}


The BIOENV analyses produced optimal correlations with the biotic matrix involving eight variables. Variables related to the metal concentrations in sediments best explained community composition, with a maximum correlation of 0.371 for $\mathrm{Pb}$ and $\mathrm{Cu}$, followed by the three variables $\mathrm{Zn}, \mathrm{Pb}$ and $\mathrm{Cd}$ with a correlation of 0.364 .

\section{Discussion}

Our results indicated that sediments from the southern basin of the Mar Menor coastal lagoon are influenced by historical mining activities developed in the adjacent mountains and show high levels of metals. Sediments influenced by the discharge of mining residuals through both wadis (BW and PW) presented metal bioavailability to benthic invertebrates (toxicity bioassays) and to marine phanerogams (bioaccumulation). The highest sediment metal concentration and toxicity levels were found in samples taken near the mouth of Beal wadi (BW), where mining wastes were discharged directly during mine exploitation. At present, due to the arid climate of the area, when torrential rains occur the mining wastes remaining in the mountains are introduced into the lagoon through the Beal (BW) and Ponce (PW) wadis. Small and not well-defined streams also occur that produce diffuse contamination around station UR.

The sediments of the Mar Menor lagoon have higher $\mathrm{Zn}$, $\mathrm{Pb}, \mathrm{Cu}$ and $\mathrm{Cd}$ concentrations than other coastal areas (e.g., Ambatsian et al., 1997; Byrne and O’Halloran, 2000). These concentrations are in agreement with those observed in previous studies in the area during the last three decades and have not undergone any noticeable change during this period (Simoneau, 1973; De Leon et al., 1982; Rodríguez et al., 2001).

The whole-sediment toxicity tests performed with the amphipods M. gryllotalpa and S. sabatieri, and the sedimentwater interface toxicity tests developed with the sea urchins, are in accordance and identified as toxic those sediments influenced by the discharge of both wadis. The toxicity results were well correlated with the SEM-AVS negative values, indicating the absence of toxicity, as demonstrated Hansen et al. (1996) in anoxic sediments, where the availability of divalent metals to organisms living in nearby oxic surface sediments or tubes has been related to AVS.

The SEM-AVS values may also be related to metal bioaccumulation in the seagrass Cymodocea nodosa. The great differences in SEM-AVS values between both wadi stations (BW and PW) might be responsible for the different pattern observed in the accumulation of metals between leaves and roots. Station BW presented very high SEM-AVS values, indicating that most of the metals were not bound to sulfides and were bioavailable, the roots being the plant fraction that presented the highest concentrations. On the other hand, stations PW, CI and CII showed higher metal concentrations in the leaf fractions and SEM-AVS values close to zero, indicating that most metals were associated with AVS, forming las que mejor explicaron la composición de la comunidad de invertebrados con una correlación máxima de 0.371 para $\mathrm{Pb}$ y $\mathrm{Cu}$, seguidas por la agrupación de las tres variables $\mathrm{Zn}, \mathrm{Pb}$ y Cd, con una correlación de 0.364 .

\section{Discusión}

Nuestros resultados indican que los sedimentos de la cuenca sur de la laguna costera del Mar Menor están influenciados por las actividades mineras históricas desarrolladas en las montañas adyacentes, mostrando altos niveles de metales. Los sedimentos influenciados por la descarga de residuos mineros a través de ambas ramblas (El Beal y Ponce) presentaron contenidos en metales que se encontraban disponibles para los invertebrados bentónicos (bioensayos de toxicidad) y para las fanerógamas marinas (bioacumulación). La máxima concentración de metales en sedimentos y los mayores niveles de toxicidad fueron encontrados en las muestras tomadas cerca de la desembocadura de la rambla del Beal (BW), a través de la cual los residuos mineros eran descargados directamente durante la explotación minera. Actualmente, debido al clima árido de la zona, cuando ocurren fenómenos de lluvias torrenciales, los residuos mineros que aun quedan en las montañas son introducidos en la laguna a través de las ramblas del Beal y Ponce. Hay incluso pequeños cursos de agua no bien definidos que producen contaminación difusa en los alrededores de la estación UR.

Los sedimentos del Mar Menor tienen mayores concentraciones de $\mathrm{Zn}, \mathrm{Pb}, \mathrm{Cu}$ y $\mathrm{Cd}$ que otras áreas costeras (e.g., Ambatsian et al., 1997; Byrne and O'Halloran, 2000). Estas concentraciones están de acuerdo con las observadas en estudios previos realizados en la zona durante las últimas tres décadas y no han mostrado cambios significativos durante este periodo (Simoneau, 1973; De Leon et al., 1982; Rodríguez et al., 2001).

Las pruebas de toxicidad con sedimentos empleando los anfípodos M. gryllotalpa y S. sabatieri, y con la interfase aguasedimento con los erizos marinos, ofrecen resultados similares e identifican como tóxicos aquellos sedimentos influenciados por la descarga de ambas ramblas. Los resultados de las pruebas de toxicidad estuvieron bien correlacionados con los valores negativos de SEM-AVS, que indican la ausencia de toxicidad, como demostró Hansen et al. (1996) en sedimentos anóxicos en los que la disponibilidad de metales divalentes para los organismos que viven en tubos o en la superficie de los sedimentos está relacionada con los AVS.

Los valores de la relación SEM-AVS también parecen estar relacionados con la bioacumulación de metales en la fanerógama marina Cymodocea nodosa. La gran diferencia en los valores de SEM-AVS entre las estaciones de las ramblas (BW y PW) podría ser la responsable de los diferentes patrones observados en la acumulación de metales entre las hojas y las raíces. La estación BW, que presentó valores muy altos de SEM-AVS indicando que la mayoría de los metales no estaban unidos a sulfuros y se encontraban biodisponibles, presentó las 
insoluble and biologically unavailable metal sulfides. Although the SEM-AVS ratio influences the availability of metals to living organisms, its role may be lower in the case of rooted aquatic plants because they transport oxygen to underground tissues, oxidizing the sulfides and reducing their effect on metal availability (Marbá and Duarte, 2001). The metal concentrations recorded in our study for $C$. nodosa may be considered to exceed the background level for non-polluted areas at stations BW and PW (Moore and Ramamoorthy, 1984) and are much higher than those found in other studies mentioned in the bibliography for $C$. nodosa (Malea and Haritonidis, 1994; Prange and Dennison, 2000; Sanchiz et al., 2000). Many metal ions, such as $\mathrm{Cd}^{2+}, \mathrm{Cu}^{2+}, \mathrm{Cr}^{3+}, \mathrm{Pb}^{2+}$, etc., are efficiently chelated by the extracellular polymeric substances secreted when bacteria and microalgae are associated with surfaces (e.g., sediment particles or plant surfaces), forming a "microbial biofilm" (Decho, 2000). The fact that sediments presented similar $\mathrm{Zn}$ and $\mathrm{Pb}$ concentrations to the leaf-biofilm at the wadi stations can be due to metal deposition over the biofilm from the stormwater runoff that introduces great quantities of metals associated with fine sediments through these two wadis.

The classical descriptive parameters employed to study the benthic community structure (Margalef richness, ShannonWiener diversity, Pielou evenness and Simpson dominance) were not clear indicators of disturbance in estuarine areas (DelValls and Chapman, 1998; DelValls et al., 1998; Drake et al., 1999). These parameters were also poor indicators of the "state of health" of the Mar Menor lagoon, where the areas contaminated by metals (BW, PW and UR) showed higher diversity values than those stations ( $\mathrm{CI}$ and $\mathrm{PH}$ ) with low or moderate metal contamination. In our case, this inconsistency was mainly due to the high abundance of just one species (S. sabatieri) in non-impacted sites (high dominance values). Metal contamination probably has a deleterious effect on the amphipod S. sabatieri, decreasing its dominance and thus increasing the diversity values of the contaminated stations. The effects of metal contamination on the benthic community might be similar to the effect of top predators that control the abundance of lower trophic levels, sustaining communities of apparent high diversity. The abundance of $S$. sabatieri was correlated with the survival percentages obtained with this species in sediment toxicity assays (Spearman correlation $r=0.62$, $P<0.01$ ). This is the first time that the amphipod $S$. sabatieri has been used to evaluate sediment toxicity and seems to be suitable for sediment toxicity determination in the lagoon, not only because of the consistency of the results but also because of its ecological significance due to its broad distribution in Mar Menor.

The multivariate techniques applied in this study provided more consistent conclusions than those obtained with descriptive analyses and seem to be a useful tool to evaluate the environmental quality of the Mar Menor lagoon. The MDS ordination technique grouped the stations into three different groups that can be classified as non-impacted (PH, CI and CII), mayores concentraciones de metales en las raíces de la planta. Por otro lado, las estaciones PW, CI y CII, que mostraron valores de SEM-AVS cercanos a cero indicando que la mayoría de los metales contenidos en los sedimentos estaban asociados a AVS formando sulfuros metálicos insolubles no disponibles biológicamente, presentaron mayores concentraciones de metales en las hojas indicando que posiblemente su absorción haya ocurrido principalmente del agua de la columna. Aunque la relación SEM-AVS influencia la disponibilidad de los metales para los organismos, su papel puede ser menor en el caso de plantas acuáticas con raíces, ya que éstas transportan oxígeno a los tejidos enterrados oxidando los sulfuros y reduciendo su efecto en la disponibilidad de los metales (Marbá y Duarte, 2001). Las concentraciones de metales encontradas en $C$. nodosa de las estaciones BW y PW en este estudio pueden considerarse por encima de los niveles de fondo para áreas no contaminadas (Moore y Ramamoorthy, 1984), y son mucho mayores que las encontradas en otros estudios con $C$. nodosa (Malea y Haritonidis, 1994; Prange y Dennison, 2000; Sanchiz et al., 2000). Muchos iones metálicos como $\mathrm{Cd}^{2+}, \mathrm{Cu}^{2+}, \mathrm{Cr}^{3+}$, $\mathrm{Pb}^{2+}$, etc., son eficientemente quelados por las substancias poliméricas extracelulares secretadas cuando bacterias y microalgas se asocian con superficies (e.g., partículas de sedimento o superficies de plantas) formando un biofilm tapete microbiano (Decho, 2000). El hecho de que los sedimentos presenten concentraciones de cinc y plomo similares a las del biofilm en las estaciones de las ramblas, puede deberse a la deposición de metales sobre el biofilm por el arrastre de aguas de tormenta que introduce gran cantidad de metales asociados con finos a través de estas dos ramblas.

Los descriptores clásicos empleados para estudiar la estructura de la comunidad bentónica (riqueza de Margalef, diversidad de Shannon-Wiener, equitatividad de Pielou y dominancia de Simpson) no resultaron claros indicadores de perturbación en áreas estuarinas (DelValls y Chapman, 1998; DelValls et al., 1998; Drake et al., 1999). Estos descriptores tambien fueron malos indicadores del "estado de salud" de la laguna del Mar Menor, donde las zonas contaminadas por metales (BW, PW y UR) mostraron mayores valores de diversidad que las estaciones con baja o moderada contaminación por metales (CI y PH). En nuestro caso, esta inconsistencia se debió principalmente a la gran abundancia de una sola especie (S. sabatieri) en las estaciones no impactadas. La contaminación por metales probablemente ha causado efectos adversos al anfípodo S. sabatieri, disminuyendo su dominancia y por tanto incrementando los valores de diversidad en las estaciones contaminadas. Los efectos de la contaminación por metales en las comunidades bentónicas podrían ser similares al efecto de los predadores que controlan la abundancia de niveles tróficos inferiores, manteniendo comunidades con aparente alta diversidad. La abundancia de $S$. sabatieri estaba correlacionada con los porcentajes de supervivencia obtenidos con esta especie en los ensayos de toxicidad con sedimento (correlación de Spearman $r=0.62 ; P<0.01$ ). Esta es la primera vez que el anfípodo $S$. sabatieri ha sido empleado para evaluar la 
moderately impacted (UR) and severely impacted (BW and PW). The wadis stations (BW and PW) showed higher presence of Polychaeta and lower of Crustacea. At both stations, the abundance of Cirratulidae (Polychaeta), which are tolerant of a wide range of environmental conditions and inhabit sandy and silty sediments, was high (Fauvel, 1975). Some species of the Cirratulidae and Nephtyidae Polychaeta families are common in estuaries, including those draining metalliferous mining regions (Geoffrey and Gibbs, 1987). The high percentage of Crustacea, the most pollution-sensitive taxon, at stations $\mathrm{PH}, \mathrm{CI}$ and CII pointed to low or moderate levels of disturbance. Metal concentrations in sediments were identified as the main parameters that determined the benthic community structure in the southern basin of Mar Menor, although other contaminants not analyzed in this study may also influence the community assemblages.

In this study we have evidenced the high load of metals in sediments of the southern basin of the Mar Menor lagoon influenced by mining wastes. The availability of metals to benthic organisms has been demonstrated through toxicity tests with amphipods and sea urchins and bioaccumulation measurements in the seagrass $C$. nodosa. This metal bioavailability seems to be closely related to the molar relation SEM-AVS and seems to influence the benthic faunal assemblages of those contaminated sediments.

\section{Acknowledgements}

The second author acknowledges the post-doc scholarship from the Ministerio de Educaçao e Cultura de Brasil (CAPES/MEC-BR/BEX2558-03/3).

\section{References}

Allen, H.E., Gongmin, F. and Deng, B. (1993). Analysis of acid volatile sulfide (AVS) and simultaneously extracted metals (SEM) for estimation of potential toxicity in aquatic sediments. Environ. Toxicol. Chem., 12: 1441-1453.

Ambatsian, P., Fernex, F., Bernat, M., Parron, C. and Lecolle, J. (1997). High metal inputs to closed seas: The New Caledonian lagoon. J. Geochem. Explor., 59: 59-74.

Buchanan, J.B. (1984). Sediment analysis. In: N.A. Holme and A.D. Mcintyre (eds.), Methods for the Study of Marine Benthos. Blackwell Scientific Publ., pp. 41-65.

Byrne, P.A. and O'Halloran, J. (2000). Acute and sublethal toxicity of estuarine sediments to the Manila clam, Tapes semidecussatus. Environ. Toxicol., 15: 456-468.

Cesar, A., Marín, L., Vita, R., Gómez, M., Jiménez, B. y Marín, A. (2000). Test de toxicidad con sedimento marino en la costa Mediterránea empleando anfípodos: Gammarus aequicauda y Microdeutopus gryllotalpa. En: G. Espindola, R. Paschoal, O. Rocha, C. Bohrer y L. Neto (eds.), Ecotoxicologia: Perspectivas para o Século XXI. Sao Carlos, RiMa, pp. 17-27.

Cesar, A., Marín-Guirao, L., Vita, R. and Marín, A. (2002). Sensitivity of Mediterranean amphipods and sea urchins to reference toxicants. Cienc. Mar., 28: 407-417.

Cesar, A., Marín, A., Marín-Guirao, L. and Vita, R. (2004). Amphipod and sea urchin tests to assess the toxicity of Mediterranean toxicidad de sedimentos y se presenta como un organismo conveniente para la determinación de toxicidad de sedimentos en la laguna, no sólo por la consistencia de los resultados sino también por su significado ecológico debido a su amplia distribución en el Mar Menor.

Las técnicas multivariantes aplicadas en este estudio ofrecen conclusiones más consistentes que las obtenidas con los análisis descriptivos y parecen ser herramientas útiles para evaluar la calidad ambiental del Mar Menor. La técnica de ordenación MDS agrupó las estaciones en tres grupos diferentes y podrían ser clasificadas como no impactadas (PH, CI y CII), moderadamente impactadas (UR) y severamente impactadas (BW y PW). Las estaciones de las ramblas (BW y PW) mostraron una mayor presencia de poliquetos y menor de crustáceos. En ambas estaciones, la abundancia de cirratúlidos (Polychaeta), tolerantes de un amplio rango de condiciones ambientales y habitantes de sedimentos arenosos y fangosos, fue elevada (Fauvel, 1975). Algunas especies de las familias de poliquetos Cirratulidae y Nephtyidae son comunes en estuarios, incluyendo aquellos que drenan regiones mineras (Geoffrey y Gibbs, 1987). El alto porcentaje de crustáceos, el grupo taxonómico más sensible a la contaminación, en las estaciones PH, CI y CII, apunta a un bajo o moderado nivel de perturbación. Las concentraciones de metales en los sedimentos fueron identificadas como los principales parámetros que determinan la estructura de las comunidades bentónicas en la sur del Mar Menor, aunque otros contaminantes no analizados en este estudio podrían estar influenciando a estas comunidades.

En este estudio hemos evidenciado la alta carga de metales de los sedimentos de la cuenca sur del Mar Menor influenciada por residuos mineros. La disponibilidad de los metales a los organismos bentónicos ha sido demostrada a través de pruebas de toxicidad con anfípodos y erizos y con medidas de bioacumulación en C. nodosa. Esta biodisponibilidad parece estar relacionada con la relación molar SEM-AVS y parece influenciar las asociaciones faunisticas bentónicas de los sedimentos contaminados.

\section{Agradecimientos}

A. Cesar agradece la beca postdoctoral del Ministerio de Educación y Cultura de Brasil (CAPES/MEC-BR/BEX255803/3).

Traducido al español por los autores.

sediments: The case of Portman Bay. Scientia Mar., 68(Suppl. 1): 205-213.

Chapman, P.M. and Wang F. (2001). Assessing sediment contamination in estuaries. Environ. Toxicol. Chem., 20: 3-22.

Clarke, K.R. (1993). Non-parametric multivariate analyses of changes in community structure. Aust. J. Ecol., 18: 117-143.

Clarke, K.R. and Gorley, R.N. (2001). PRIMER v5: User Manual/ Tutorial. Plymouth, UK. 
Clarke, K.R. and Warwick, R.M. (2001). Change in marine communities: An approach to statistical analysis and interpretation. 2nd ed. Plymouth Marine Laboratory, UK.

Decho, AW. (2000). Microbial biofilms in intertidal systems: An overview. Cont. Shelf Res., 20: 1257-1273.

De Leon, A.R., Guerrero, J. and Faraco, F. (1982). Evolution of the pollution of the coastal lagoon of Mar Menor. VI Journées Étud. Pollutions, Cannes, CIESM.

DelValls, T.A. and Chapman, P.M. (1998). The use of multivariate analysis to link the sediment quality triad components to sitespecific sediment quality values in the Gulf of Cádiz (Spain) and in San Francisco Bay (USA). Cienc. Mar., 24: 313-336.

DelValls, T.A., Conradi, M., García-Adiego, E., Forja, J.M. and Gómez-Parra, A. (1998). Analysis of macrobenthic community structure in relation to different environmental sources of contamination in two littoral ecosystems from the Gulf of Cádiz (SW Spain). Hydrobiologia, 385: 59-70.

Drake, P., Baldó, F., Sáez, V. and Arias, A. (1999). Macrobenthic community structure in estuarine pollution assessment on the Gulf of Cádiz (SW Spain): Is the phylum-level meta-analysis approach applicable? Mar. Pollut. Bull., 38: 1038-1047.

Fauvel, P. (1975). Fauna de France: Polychètes. Fédération Française des Sociétés de Sciences Naturelles. Office Central de Faunistique. Kraus Reprint. Neudeln/ Liechtenstein.

Geoffrey, W.B. and Gibbs, P.E. (1987). Polychaetes as indicators of heavy-metal availability in marine deposits. In: J.M. Capuzzo and D.R. Kester (eds.), Oceanic Processes in Marine Pollution. Vol. 1. Biological Processes and Wastes in the Ocean. Krieger Publ. Co., Melbourne, Florida, pp. 37-49.

Gulley, D.D., Boelter, A.M. and Harold, L.B. (1991). TOXSTAT® Computer Program. Version 3.3. Univ. of Wyoming, Laramie.

Gundersen, P., Olsvik, P.A. and Steinnes, E. (2001). Variations in heavy metal concentration in two mining-polluted streams in central Norway. Environ. Toxicol. Chem., 20: 978-984.

Hamilton, M.A., Russo, R.C. and Thurston, R.V. (1977). Trimmed Spearman-Karber method for estimating median lethal concentrations in toxicological bioassays. Environ. Sci. Tech., 11: 714-719; correction 12: 417, 1978.

Hansen, D.J., Berry, W.J., Mahony, J.D., Boothman, W.S., Di Toro, D.M., Robson, D.L., Ankley, G.T., Ma, D., Yan, Q. and Pesch, C.E. (1996). Predicting the toxicity of metal-contaminated field sediments using interstitial concentration of metals and acidvolatile sulfide normalizations. Environ. Toxicol. Chem., 15: 2080-2094.
Ingersoll, C.G. (1995). Sediment test. In: G.M. Rand (ed.), Fundamentals of Aquatic Toxicology. Taylor and Francis, USA, pp. 231-255.

Malea, P. and Haritonidis, S. (1994). Local distribution and seasonal variation of $\mathrm{Fe}, \mathrm{Pb}, \mathrm{Zn}, \mathrm{Cu}, \mathrm{Cd}, \mathrm{Na}, \mathrm{K}, \mathrm{Ca}$ and $\mathrm{Mg}$ concentrations in the seagrass Cymodocea nodosa (Ucria) Aschers in the Antikyra Gulf, Greece. Mar. Ecol., 16(1): 41-56.

Marbá, N. and Duarte, C.M. (2001). Growth and sediment space occupation by seagrass Cymodocea nodosa roots. Mar. Ecol. Prog. Ser., 224: 291-298.

Moore, J.W. and Ramamoorthy, S. (1984). Heavy Metals in Natural Waters. Springer, New York, Berlin, Heidelberg, Tokyo.

Prange, J.A. and Dennison, W.C. (2000). Physiological responses of five seagrass species to trace metals. Mar. Pollut. Bull., 41: 327-336.

Sanchiz, C., García-Carrascosa, A.M. and Pastor, A. (2000). Heavy metal contents in soft-bottom marine macrophytes and sediments along the Mediterranean coast of Spain. Mar. Ecol., 21(1): 1-16.

Simoneau, J. (1973). Mar Menor: Evolution sedimentologique et geochimique recente du remplissage. Thesis, Université Paul Sebatier de Tolouse, France.

Somerfield, P.J., Gee, J.M. and Warwick, R.M. (1994). Soft sediment meiofaunal community structure in relation to a long-term heavy metal gradient in the Fal estuary system. Mar. Ecol. Prog. Ser., 105: 79-88.

Tabachnick, B.G. and Fidell, L.S. (1996). Using Multivariate Statistics. Harper Collins, New York.

US Environmental Protection Agency (1993). A Linear Interpolation Method for Sublethal Toxicity: The Inhibition Concentration (ICp) Approach. Duluth, MN.

US Environmental Protection Agency (1994). Methods for assessing the toxicity of sediment-associated contaminants with estuarine and marine amphipods. EPA/ 600/ R-94/025. Narragansett, RI.

US Environmental Protection Agency. (1995). Short-term methods for estimating the chronic toxicity of effluents and receiving waters to west coast marine and estuarine organisms. EPA/ 600/ R-95-136. Cincinnati, Ohio.

Verdardo, D.J., Forelich, P.N. and McIntyre, A. (1990). Determination of organic carbon and nitrogen in marine sediments using the Carlo Erba NA-1500 analyzer. Deep-Sea Res., 37: 157-165. 